\title{
Trans-Human and Post-Human: A Challenge for the Human and Philosophical Sciences
}

\author{
Marta Toraldo1, Domenico Maurizio Toraldo ${ }^{2 *}$ \\ ${ }^{1}$ University of the Salento, Lecce, Italy \\ ${ }^{2}$ Department of Rehabilitation, Cardio-Respiratory Unit Care, ASL Lecce, “V. Fazzi” Hospital, Lecce, Italy \\ Email: *d.torald@tin.it
}

How to cite this paper: Toraldo, M., \& Toraldo, D. M. (2019). Trans-Human and Post-Human: A Challenge for the Human and Philosophical Sciences. Open Journal of Philosophy, 9, 54-61. https://doi.org/10.4236/ojpp.2019.91005

Received: January 22, 2019

Accepted: February 23, 2019

Published: February 26, 2019

Copyright (c) 2019 by author(s) and Scientific Research Publishing Inc. This work is licensed under the Creative Commons Attribution International License (CC BY 4.0).

http://creativecommons.org/licenses/by/4.0/

(c) (i) Open Access

\begin{abstract}
This paper describes the concept of scientific knowledge in both modern and post-modern society. It presents a brief analysis of how the value of scientific knowledge is changing in contemporary society and describes future developments linked to the new concept of trans-humanism. The term "post-human" refers to a progressive alteration of human characteristics by means of genetic and electronic manipulation that results in an anthropological mutation, which is a prelude to the advent of a new, and post-human species. The term "trans-human" means more than human, beyond human, transcending the limits of the human condition and aspiring to an almost divine superior meaning. This new modified condition of human beings is defined as post-human and the process of change is described within the cultural framework of humanism. Trans-humanism as a term refers to a philosophical doctrine belonging to the family of contemporary progressive ideologies in which trans-humanist intellectuals analyse and promote technologies aimed at overcoming the limits of human nature. Analyzing the trends, the anthropological implications and the cultural impact of such technologies, this new philosophical/scientific doctrine tends to emphasise the positive aspects of scientific development, but without underestimating the potential dangers arising from the misuse of technology. The open ethical challenge of trans-humanism is twofold: 1) the physical improvement of human beings with reference to the new trans-human concept of human nature; 2) the development of a trans-human being that can fulfil humanity's dream of escaping the bonds of its condition, acquiring a "cybernetic nature" free from pain and suffering.
\end{abstract}

\section{Keywords}

Post-Human, Trans-Human, Robotics, Cybernetics, Neuroscience 


\section{Introduction}

In contemporary usage, the term "postmodern" is used to indicate the crisis of modernity in mature capitalist societies, faced since the 1960s with the global and planetary dimensions of the economy and financial markets, the intensity of advertising messages, the intrusion of television and, more recently, the flow of information on electronic networks. In contrast to the typical characteristics of modernist ideology, the postmodern cultural and anthropological condition is characterized by a reading of history and anthropology that spurns scientific finalism, and by the abandonment of humanity's great ethical projects. At the dawn of modernity and modern society, the awareness of living in an age marked by profound social changes gave rise to sociology. For this new discipline, the fundamental characteristics of society-dominated as it was by industrial capitalism-were the revolution in social relations, the prevalence of an instrumental rationality in all areas of social life and the emergence of a polytheism of cultural values, in constant conflict with each other. Modern society is characterized by a tendency to see cognitive novelty in the philosophical field as an improvement on the previous reality. This translates to a propensity to identify what is new with what is better; a tendency to conceive history in terms of the emancipation of human beings, a progressive path of improvement leading towards freedom, equality and collective economic and social well-being. In this view, human beings are the dominators of nature and the masters of reality via the neo-positivist exaltation of science.

In contrast to these key aspects of modernity, the post-moderns posited a constellation of ideas and numerous fragmented and uncertain forms of knowledge (Hutcheon, 2003, eBook). Post-modern society, as it has developed in Western societies, is characterized by: 1) the development of advanced and globalized capitalism in which the logic of production and exchange of goods and the market prevails over all other human values; 2) a situation in which knowledge is no longer identified with science and with the experimental method; 3) the intrusion and aggressiveness of the mass media and television in the daily life of citizens; 4) the continuous flow of information and news on social and other online networks; 5) a rejection of previously accepted all-inclusive theories of knowledge that can explain all kinds of phenomena; 6) a tendency to consider knowledge, as an absolute value, to be "weak", "unstable" and "uncertain" (Lyotard, 1979: pp. 18-31).

The post-modern approach that has established itself over the last twenty years, in Western societies in particular, challenges the idea of a global human of the classical type understood as the embodiment of harmony, beauty and balance, the reference point of all knowledge, and the dominant species in nature. In this view, human beings can no longer claim to occupy the central position in the current systems of production and philosophical-scientific knowledge, which in contrast are technologically mediated and guided by computer networks and complex computational processes on multiple levels of abstraction of thought 
(Firat \& Dholakia, 2006: pp. 123-124).

The relationship between post-modernism and post-industrial society is particularly close. The mediating element is the pluralistic nature of this society, of which postmodernism aims to be the reflected consciousness. Indeed, as we have seen, against all forms of homogenization and planning, postmodernism strives to assert the demands of multiplicity and difference, to the point of becoming the spokesperson of the polycentric and diversified physiognomy of today's multi-racial and multi-cultural societies, shorn of any ontological finalism (Sarup, 1993: pp. 123-134). Hence, the postmodern project of a humanity in the plural, happy to abandon the classical dream of monolithic, universalistic knowledge, of the one and only truth, of a single faith and a unique system of scientific and ethical values; history is no longer a unitary thread leading to progress, but on the contrary, manifests itself in the plurality of non-formal information.

The concept of postmodern also includes the concept of "weak" thought, that is, the philosophical attitude that arises from the crisis of certainties and absolute values in the cognitive field, in which knowledge is not identified with science and the experimental method, but is rather anarchic and fragmented, and scientific truths are subordinate to practical efficiency. The crisis of humanist anthropocentrism coincides with the critique of the supremacy of the human species in the universe (Barry, 2002: pp. 61-94).

Trans-humanism, or "beyond the human", refers to the cultural movement arising from the crisis of certainty in the medical-scientific field and promotes the use of the most advanced scientific and technological discoveries aimed at increasing people's physical and cognitive abilities. The ultimate aim is to improve aspects of the human condition generally assessed as "undesirable" (for example, disease and aging), a perspective that tends to a possible future post-human transformation.

Trans-humanism is a contemporary intellectual movement of the philosophical and scientific type that arises as a consequence of post-modernity. It aims to give a positive response to the post-modern crisis, seeking technical-scientific solutions and innovative practices that can improve the human race, enhancing intellectual abilities and physical and psychological performance. This movement is not associated with a homogeneous and compact theoretical field, but is rather a multiplicity of heterogeneous, fragmented lines of research, held together by a leading idea: the belief that the old humanism has reached the limits of what it can achieve and post-modernity is not able to give positive answers to the crisis of contemporary knowledge. The biological and cultural limits of man can be overcome using the skills of genetic engineering, robotics, nanotechnology and artificial intelligence, endowing the brain and the human body with new genetic and technological potential that can change not just humans but human nature. The term "trans-humanism" thus indicates a philosophical doctrine belonging to the family of contemporary progressive evolutionary ideologies whose proponents create, study and promote technologies aimed at overcoming natural 
human biological limits.

\section{Post-Humanism and Trans-Humanism in Neuroscience}

The definition of "post-human" lies in a progressive alteration or loss of human characteristics by means of genetic and electronic manipulation that results in anthropological and philosophical mutation, perhaps a prelude to the advent of a new, post-human species. The post-human arrives by means of chips and sensors. In contrast, the term "trans-human" means more than human, that is, beyond human, transcending the limits of the human condition and acquiring a superior, quasi-divine meaning. It may be understood today as referring to the human condition following the post-human modifications. The roots of trans-humanism are to be sought further back in time however, somewhere on the journey from Renaissance humanism through the Enlightenment and positivism to the crossover of F. Nietzsche's "superman" and futurism. Trans-humanism, therefore, originates from humanism, from which it takes some elements such as respect for reason and the value of human sciences, the commitment to progress and the value of human existence. However, it differs from humanism because it recognizes and anticipates the cognitive changes in human nature that will result from the progress of the various sciences and technologies.

The interdisciplinary and multidisciplinary research into post humans in a technological sense, oriented towards the hard sciences (cybernetics, nanotechnologies, etc.) has opened up to evolutionary biology, where the post-human world entails the overcoming of human nature. The debate originated in the USA with the publication of the book published by J Brockman entitled "Machines That Think. The Future of Artificial Intelligence" by Toby Walsh (Brockman, 2015, Edge) which foresees the development of artificial thinking machines that overtake the human mind. In this regard, Stephen Hawking (Molina, USA TODAY, 2018) stated that "The development of a full artificial intelligence could mean the end of the human race". Others, on the contrary, have theorized a new era of "super-men", in which intelligent devices can exponentially extend and amplify human capabilities

(http://www.transhumanism.org/). From the philosophical point of view, if we accept the scientific theory of evolution, our cognitive abilities can evolve and improve in relation to stimuli and opportunities for external interactions of the cultural and environmental type (Bostrom, 2003).

Software and hardware inserted as devices in human tissues create a new bionic being who possesses robotic, cyber-like capabilities, modifying the fundamental processes of human perception and experience, changing the awareness of the self, of one's own body and sexuality, and the perception of reality. The modified man or woman becomes a new human being, with new abilities, but also with new problems (Harpham, 2012: pp. 101-112) and (Horgan, 1997) and (Mosconi, 2015, Special Issue: pp. 465-482).

The cyber approach to the human is thus a relationship in which the connection between body and machine is symbiotic and can therefore be better de- 
scribed as a bond of mutual dependency. In this way, human beings can choose to artificially modify themselves, becoming a cyborg, a cybernetic body, which gives rise to a new way of existing (Rose, 2005: pp. 125-183) and (Parkhurst, 2016: pp. 91-103).

Today we often talk about robots, cyborgs, androids and so on. We have inextricably entangled man-the-creation-of-God and man-the-creator, once conceivable only in science fiction films, with effects not only on science but also on philosophical, anthropological, sociological and even theological discourse (Proust, 2011: pp. 153-173).

We may present (Jotterand, 2010a: pp. 45-52) the meaning of "post-human" on three levels. The first is the literal meaning of human-machine hybridization, in which man is considered as a "human body" that is improved by means of a simple technological substitution of part of it with artefacts, be they biological (genetic) or mechanical (bionic or robotic and in any case cybernetic-digital). This implies a human being that is physically modified and partly "re-made" or even completely redesigned/regenerated by human beings themselves by means of technology. In this way, human beings are more and more assimilated to the products of technology and therefore to mechanical phenomena. They become dehumanized and objectified, in the sense of literally becoming an object. A second level of meaning (Bredenoord et al., 2010: pp. 55-57) is represented by post-humanism in an abstract sense, i.e. the product of the crisis of the anthropocentric vision associated with the Italian Renaissance of the sixteenth century, whose hierarchical world view was relentlessly undermined throughout the twentieth century (e.g. by structuralism, systems theory, Heidegger etc.). These very different currents, each from a different point of view, demolished the Renaissance idea of undisputed human supremacy.

Finally, there is a third level of meaning (Hayles, 2011: pp. 215-226; Glenn \& Dvorsky, 2010: pp. 57-58) which has an "epistemic" character and which concerns the constitution of the new technological human being in the geography of knowledge, its emergence as an object of knowledge, through human sciences, and its regulatory principle. This is the model that was presented in the Übermensch of Nietzsche and in the "death of man" by Foucault. In this sense, the act of going beyond the human is placed on the same level as the act of going beyond the divine in Nietzsche's motto "God is dead". Thus it is as if we were saying "man is dead". In other words, it means passing over to another system, in which the role of the "old" human beings is becoming inessential, as that of God became in the climate of nineteenth-century positivism (Sandler \& Basl, 2010: pp. 63-66).

The post-human thus involves not just a change of organs, e.g. a mechanical hand instead of the natural one, but a change in "worldview", which also makes man's reparability even more acceptable (Jotterand, 2010b: pp. 6-8).

Finally, trans-humanism in the perspective of neurosciences tends to focus on an improvement of the capacity of thought, assuming that continuing research can overcome human biological limits, enabling the self-repair of cognitive functions (see Figure 1). 


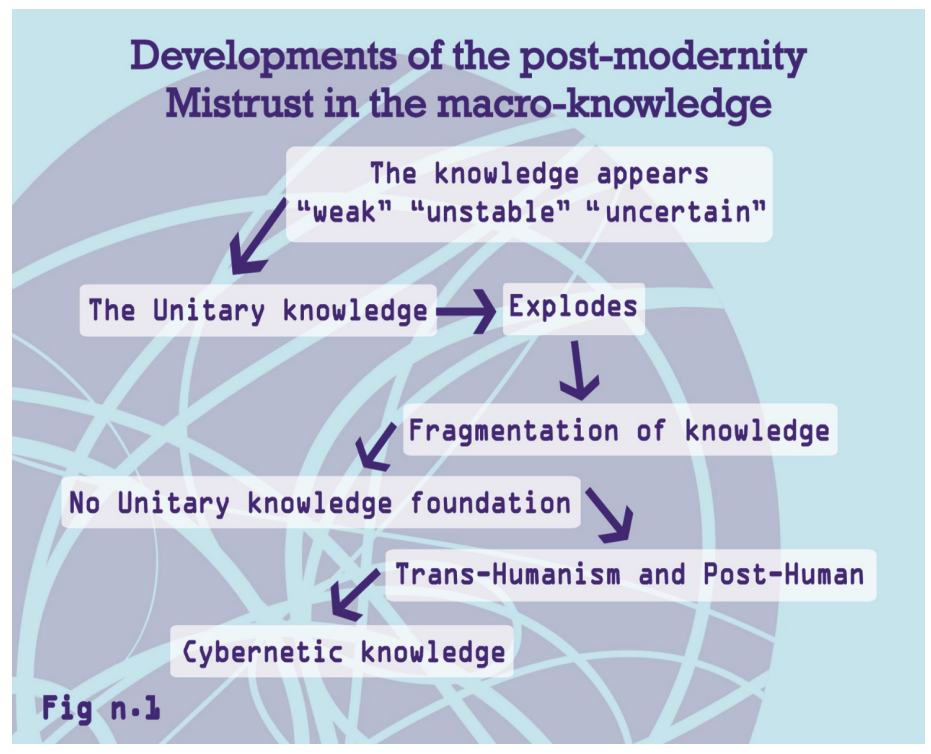

Figure 1. Evolution of the concept of scientific knowledge ${ }^{1}$.

In chapter four of "Citizen Cyborg" (Hughes, 2004), entitled "getting smarter", the sociologist James Hughes shows that more than 40 "smart drugs" have undergone clinical trials to improve memory consolidation, neural plasticity and the speed of synaptic transmission of information in the brain. A possible goal, according to the author, is to develop medicines that favor the self-repair of the damaged brain, such as the use of antidepressants able to enhance the personality and improve creativity, the use of gene therapies that block the process of cellular aging, etc.

\section{Conclusion}

In conclusion, the term "post human" can be defined as a progressive alteration

${ }^{1}$ With reference to Figure 1, the cardinal characteristics of the philosophy of modernity are the tendency to identify what is new from a knowledge point of view with all that is best, and to identify what happened in the past as something already surpassed and thus no longer useful. In addition, modernity affirms that human history leads to the emancipation of peoples, and that philosophers are the cultural and spiritual guides in this difficult journey of discovery. Modern philosophy affirms that the exaltation of science as a tool for conquering nature and philosophical reason is a product of scientific reasoning itself. In contrast, post-modern philosophy has no faith in all-embracing and absolute philosophical theories of knowledge. Post-modernism rejects the emphasis on the "new", does not see history as a universal positive process and distrusts all-embracing and legitimising macro-forms of knowledge. In this way, post-modern knowledge appears "weak", "unstable" and uncertain. A key characteristic of the philosophy of post-modernism is the lack of interest in the new. Novelty is no longer valuable in itself: it is neither better nor preferable. In addition, post-modern philosophy rejects the notion of human beings as the lords of nature. History is no longer an unbroken process that leads towards good and progress in an optimistic sense. On the contrary, it is merely a quantity of information, of journalistic stories. Post-modernism does not seek to be a philosophical and cultural avant-garde that "surpasses" previous ideas, but rather sees itself as the end of all cultural avant-gardes, a state in which knowledge is no longer identified with science and the experimental method. From the methodological point of view, scientific discovery is anarchic and irregular. Post-human knowledge is all about robotics and cybernetics. Knowledge is thus dehumanised, cybernetic in that it involves a fusion of human nature with the machine, and scientific knowledge lies in the emancipation and higher self-awareness of the quasi-divine human-machine. 
and/or loss of the characteristics of human beings. It is the result of genetic and electronic manipulation, a fully-fledged anthropological and philosophical mutation, perhaps a prelude to the advent of a new post-human species, with chips and sensors implanted in the brain. In contrast, the term "trans-human" means more than human, beyond human, and transcending the limits of the human condition. It thus aspires to a higher, quasi-divine meaning which is logically subsequent to post-human. We are thus on the eve of an epoch-making change in the very nature of the human body, which, technologically modified, becomes post-human and thus trans-human. Awareness of this radical shift in the path of human progress has prompted an increasing number of philosophers to introduce a new note of reflection into the contemporary debate and to coin a new term, "trans-human", to describe it. On the basis of the above considerations, an initial response could be the following: "post-humanism" is usually defined as a new philosophy according to which the biological nature of the human body, including the brain, does not constitute the limit of human potential. Rather, this nature can and must be transcended via the implementation of technological prostheses on the "biological body" in order to achieve a trans-human condition.

The ethical challenge posed by trans-humanism can be summarized in two reflections that remain open to multiple solutions: 1) the affirmation of the new trans-human concept of human nature will qualitatively improve overall mental and biological health; 2) the development of a "trans-human being" can fulfil the dream of escaping from the bonds of the human condition, enabling humanity to acquire a "cyber nature", free from pain and suffering.

Finally, as a philosophical/scientific movement, trans-humanism presents itself as an opportunity for humanity, helping to improve biological and technological knowledge and to explore and understand the limits of man. The post-human paradigm must engage with contemporary neurosciences, in which the theme of neural plasticity and the concept of the extended mind are at the heart of the research, potentially providing useful indications for health professionals (from biotechnology to nanotechnology, robotics, medicine etc.) involved in the search for new tools aimed at improving the quality of life and health of humanity.

\section{Conflicts of Interest}

The authors declare no conflicts of interest regarding the publication of this paper.

\section{References}

Barry, P. (2002). Beginning Theory: An Introduction to Literary and Cultural Theory (2nd ed., pp. 61-94).

Bostrom, N. (2003). Intensive Seminar on Transhumanism. New Haven: Yale University Press.

Bredenoord, A. L., van der Graaf, R., \& van Delden, J. J. (2010). Toward a "Post-Posthuman Dignity Area" in Evaluating Emerging Enhancement Technologies. The American Journal of Bioethics, 10, 55-57. 
Brockman, J. (2015). What to Think about Machines That Think. Edge Series, New York: Harper Perennial.

Firat, A. F., \& Dholakia, N. (2006). Theoretical and Philosophical Implications of Postmodern Debates: Some Challenges to Modern Marketing. Sage Journals, 6, 123-162.

Glenn, L. M., \& Dvorsky, G. (2010). Dignity and Agential Realism: Human, Posthuman, and Nonhuman. The American Journal of Bioethics, 10, 57-58.

Harpham, G. G. (2012). The Posthuman: Without It, Nothing Else Is Possible. Interdisciplinary Science Reviews, 3, 101-112.

Hayles, N. K. (2011). Wrestling with Transhumanism. In G. R. Hansell, W. Grassie et al. (Eds.), Transhumanism and Its Critics (pp. 215-226). Philadelphia, PA: Metanexus Institute.

Horgan, J. (1997). The End of Science. Facing the Limits of Knowledge in the Twilight of the Scientific Age. New York: Broadway Books.

Hughes, J. (2004). Citizen Cyborg. Why Democratic Societies Must Respond to the Redesigned Human of the Future. Cambridge, MA: Westview Press.

Hutcheon, L. (2003). The Politics of Modernism. eBook, London: Imprint Routledge.

Jotterand, F. (2010a). Human Dignity and Transhumanism: Do Anthro-Technological Devices Have Moral Status? The American Journal of Bioethics, 10, 45-52. https://doi.org/10.1080/15265161003728795

Jotterand, F. (2010b). Response to Open Peer Commentaries on "Human Dignity and Transhumanism: Do Anthro-Technological Devices Have Moral Status?" The American Journal of Bioethics, 10, 6-8.

Lyotard, G. B. (1979). The Post-Modern Condition: A Report Knowledge (pp. 18-31). Minneapolis: University of Minnesota.

Molina, B. (2018). Stephen Hawking Warns That AI, "Superhumans" Could Wipe Humanity in Posthumous Book Published 5:52 AM. USA TODAY.

http://www.transhumanism.org/

Mosconi, G. (2015). Centro Studi Psicologia e Letteratura. http://centrostudipsicologiaeletteratura.org/

Parkhurst, A. (2016). The Human Figure and Urban Ground: Cyborgs and the City. The New Bioethics, 22, 91-103. https://doi.org/10.1080/20502877.2016.1194659

Proust, J. (2011). Cognitive Enhancement, Human Evolution and Bioethics. Journal International de Bioéthique, 22, 153-173. https://doi.org/10.3917/jib.222.0153

Rose, S. (2005). The Future of the Brain: The Promise and Perils of Tomorrow's Neuroscience. Oxford: Oxford University Press.

Sandler, R., \& Basl, J. (2010). Transhumanism, Human Dignity, and Moral Status. The American Journal of Bioethics, 10, 63-66. https://doi.org/10.1080/15265161003714019

Sarup, M. (1993). An Introductory Guide to Post-Structuralism and Postmodernism (pp. 123-134). Athens: University of Georgia Press. 